\title{
Influence of Transphyseal Pin Placement on Bone Growth: an Experimental Study in Pigs
}

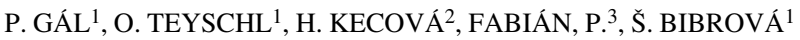 \\ ${ }^{1}$ Department of Pediatric Surgery, Orthopaedics and Traumatology, Medical Faculty, \\ Masaryk's University, Brno, Czech Republic \\ ${ }^{2}$ Department of Surgery and Orthopaedics, Small Animal Clinic, Faculty of Veterinary Medicine, \\ University of Veterinary and Pharmaceutical Sciences, Brno, Czech Republic \\ ${ }^{3}$ Department of Pathology, Medical Faculty, Masaryk's University, Brno, Czech Republic
}

\section{Received May 16, 2002}

Accepted July 19, 2002

\section{Abstract}

Gál P., O. Teyschl, H. Kecová, P. Fabián, S̆. Bibrová: Influence of Transphyseal Pin Placement on Bone Growth: an Experimental Study in Pigs. Acta Vet. Brno 2002, 71: 319-325.

The aim of this study was to determine the influence of two Steinmann pin diameters inserted in different numbers and directions into distal radial physis on longitudinal growth of this bone.

The influence of transphyseal pin placement on the growth of radius was evaluated in 30 twomonths-old piglets. Animals were divided into groups A $(n=10), B(n=5), C(n=5)$ and D $(n=$ 10) according to four different combinations of pin diameter and number of implants placed through the distal radial physis.

In animals of the group A, placement of two crossed Steinmann pins of $1.7 \mathrm{~mm}$ diameter through the distal radial physis did not influence the growth of the bone. The growth of radius in animals of groups B (3 pins of $1.7 \mathrm{~mm}$ diameter placed), C ( 2 crossed pins of $2.5 \mathrm{~mm}$ diameter inserted) and $\mathrm{D}$ ( 3 parallel pins of $2.5 \mathrm{~mm}$ diameter) was significantly altered (Student's $t$-test).

The differences in the growth of radius in animals of groups $\mathrm{B}$ and $\mathrm{C}$ differing in the diameter and number of inserted pins and the technique of pin placement were found (K-W ANOVA). Histology showed that the diameter of the implant influences the degree of ossification in the area of pin passage through the distal radial physis and thus indirectly the growth of this bone.

These experimental findings suggest, that during pinning of growth plate fractures the diameter, number of pins and insertion technique should be considered, because possible physeal damage caused by the implants can produce bone bridge formation with consequent growth disturbance.

Physis, growth disturbance, injury, pig

Fractures in children, like in growing animals, differ in some features from fractures encountered in adults and may be accompanied by certain complications (Rockwood et al. 1984; Havránek 1991; Nečas 1996; Gál 1999; Dvořák et al. 2000). In the skeleton of growing individuals, the most susceptible to injury is the growth plate. Therefore, trauma commonly results rather in separation in the physis, than in joint luxation (Rockwood et al. 1984; Havránek 1991; Bojrab 1993; Slatter 1993; Nečas 2001). Nowadays, physeal injuries amount to $20 \%$ of all skeletal injuries in children. Treatment of these injuries has been developed from simple conservative (passive) methods of therapy to more aggressive (traction) techniques of fixation or even to methods of closed reduction of fracture fragments using percutaneous fixation (Langenskiold 1981; Rockwood et al. 1984; Gomes and Volpon 1993; Olmstead 1995; Partio et al. 1997; Fossum 1997; Nečas 1998a; Nečas 1998b; Gál 1999; Hulse and Johnson 1999). The method of stable intramedullar pinning is currently also used (Métaizeau et al. 1980; Métaizeau 1983). Unsatisfactory results of physeal fracture treatment in children occur in about $5 \%$ of cases (Rockwood et al. 1984).

There are five types of physeal injuries according to Salter-Harris (1963). Damage to 
normal chondrogenesis in traumatised physis may result in bone bridging between the epiphysis and metaphysis and thus affect the growth of the bone. Dependent on their localisation in the physis, bone bridges are classified according to Bright as peripheral, central and combined (cit. Rockwood et al. 1984). Depending on the aetiology posttraumatic and osteonecrotic bone bridges are recognised (Von Laer 1984). Therapy of sequelae of bone bridges may be very difficult in both humans and animals (Kersh aw and Kenwright 1993; Park et al. 1994; Howe and Engesaeter 1997; Johnson et al. 1998).

It is currently disputed whether to perform osteosynthetic procedures in children suffering from injury to the growth plate, or choose a more conservative approach. At our department, most cases of fractures in the physis are reduced and immobilised by stable fragment fixation using transphyseally placed implants. The aim of this experimental study was to find out the influence of Steinmann pins (1.7 and $2.5 \mathrm{~mm}$ diameter), inserted in different numbers and directions (crossed and parallel pins) into the distal radial physis, on the growth of this bone.

Materials and Methods

Domestic pig was selected as an experimental animal model because of similarity in the structure of growth plates in piglets and humans. The experiment was carried out on the growth plate of distal radius. In pigs the growth plate of distal radius closes at about 3 years of age, while in children between the $17^{\text {th }}$ and $19^{\text {th }}$ years of age. Thus, one month of skeletal development in the piglet corresponds to about one half a year of development in the child.

A total number of 30 two-month-old piglets were included in the experiment. Animals were divided into groups $A(n=10), B(n=5), C(n=5)$ and D $(n=10)$ according to four different combinations of Steinmann pin diameter, number of implants and direction of placement through the distal radial physis as mentioned in Table 1. Animals were under general anaesthesia during all surgeries. As pre-medication we used mixture of xylazine ( $2 \mathrm{mg} / \mathrm{kg}$ body weight), ketamine ( $2 \mathrm{mg} / \mathrm{kg}$ body weight), zolazepam ( $2 \mathrm{mg} / \mathrm{kg}$ body weight $)$ and tiletamine ( $2 \mathrm{mg} / \mathrm{kg}$ body weight), given intramuscularly. General inhalation anaesthesia was maintained using $\mathrm{N}_{2} \mathrm{O}+\mathrm{O}_{2}(2: 3)$. Analgesia was enhanced by butorphanol $(0.2 \mathrm{mg} / \mathrm{kg}$ body weight $)$. As a prophylaxis, we used amoxicillin clavulanate, given intramuscularly, at the dose of $1 \mathrm{ml} / 20 \mathrm{~kg}$ of body weight once daily for 5 days. Steinmann pins were left in situ for 14 days and then extracted. One month later, the animals were euthanized using thiopental at the dose of $3 \mathrm{~g}$ pro toto i.v.

Table 1

Technique of implant placement

\begin{tabular}{|c|c|c|c|}
\hline \multicolumn{3}{|c|}{ Technique of implant placement } \\
\hline Group & Number of animals & Type of implants placed & Total area of implants \\
\hline A & 10 & 2 crossed pins of $1.7 \mathrm{~mm}$ diameter & $3.4 \mathrm{~mm}$ \\
\hline B & 5 & 3 parallel pins of $1.7 \mathrm{~mm}$ diameter & $5.1 \mathrm{~mm}$ \\
\hline C & 5 & 2 crossed pins of $2.5 \mathrm{~mm}$ diameter & $5.0 \mathrm{~mm}$ \\
\hline D & 10 & 3 parallel pins of $2.5 \mathrm{~mm}$ diameter & $7.5 \mathrm{~mm}$ \\
\hline
\end{tabular}

Prior to the operation, after implant placement, and following the removal of implants, we took radiographs of antebrachial bones (non-operated $=$ control bones, and operated $=$ experimental bones) using mediolateral and craniocaudal projections. Three independent surgeons measured the length of the radius using the above-mentioned radiographs. The influence of passage of the implants through the distal radial physis on the growth of this bone in individual groups of experimental animals was statistically evaluated by the Student's $t$-test. The evaluation of influence of Steinmann pins of different diameters, numbers and technique of passage through the distal physis of radius was based on the non-parametric Kruskal-Wallis single-factor analysis of variance (K-W ANOVA).

Blocks of the bones with growth plates were removed from cadavers of operated animals after euthanasia. Samples were fixed in $10 \%$ solution of buffered formalin for $48 \mathrm{~h}$. Then, they were decalcified in a solution of hydrochloric acid and ferric chloride (changed every $12 \mathrm{~h}$ ) for 5 to 8 days. Following complete decalcification, the samples were divided using a kitchen cutting device into sections 4 to $5 \mathrm{~mm}$ wide so as to reveal the longitudinal axis of the canal drilled during the surgery. Parts of the growth plate with the examined lesion were excised together with at least $1 \mathrm{~cm}$ of the surrounding tissue. These samples were histologically processed using hematoxylin and eosin staining. Sections $6 \mu \mathrm{m}$ thick were examined and photographed using an optic microscope Nikon Eclipse 1000.

The following changes were evaluated histologically:

- presence and width of newly formed cancellous bone trabeculae in the area of passage of the drilling canal through the growth plate, 
- presence, size and number of osteoblasts on the surface of these trabeculae,

- degree of transformation of fibrous tissue between bone trabeculae to haematopoietic bone marrow.

The above mentioned parameters were evaluated using a three-grade scale $0-1-2$ corresponding to the importance of changes (Table 2). The sum of evaluated parameters in each histological specimen reflected the degree of intensity of ossification. The higher the sum of parameters, the higher the degree of ossification observed.

Examining twelve technically best processed histological specimens of the distal radial physis we evaluated the difference between passage of implants of two sizes (six and six physeal specimens with Steinmann pins of 1.7 and $2.5 \mathrm{~mm}$ in diameter placed, respectively).

Table 2

Evaluation of histological parameters

\begin{tabular}{|l|c|c|}
\hline \multicolumn{2}{|c|}{ Evaluation of histological parameters } \\
\hline Parameter & Way of evaluation & Scale \\
\hline Width of trabecullae & From the most narrow to the most wide & $0-1-2$ \\
\hline Osteoblastic borders & From the most prominent to the minimum & $0-1-2$ \\
\hline Bone marrow & From the fibrous to the hematopoietic one & $0-1-2$ \\
\hline
\end{tabular}

\section{Results}

Results of morphometry measurements are summarised in Table 3. Evaluating these results statistically (Student's $t$-test), we found that the passage of two Steinmann pins of 1.7 $\mathrm{mm}$ diameter placed in a crosswise manner through the distal physis of radius (Plate VIII, Fig. 1) in group-A-animals did not influence the further growth of the bone. There was no difference in the growth between the control (non-operated) and experimental (operated) bone in this group. The growth of radius was altered in group-B-animals following placement of 3 implants of $1.7 \mathrm{~mm}$ diameter. Significant differences (Student's $t$-test) in the growth of radius were also found in group-C-animals following crosswise placement of 2 implants, $2.5 \mathrm{~mm}$ in diameter, through the distal radial physis. In group-D-animals, placement of 3 parallel Steinmann pins, $2.5 \mathrm{~mm}$ in diameter, significantly altered the growth of the radius (see Table 4).

Table 3

Morphometric evaluation

\begin{tabular}{|c|c|c|c|c|c|c|c|c|c|c|c|c|c|c|c|c|}
\hline \multirow{4}{*}{ 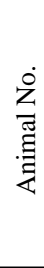 } & \multicolumn{16}{|c|}{ Morphometric evaluation } \\
\hline & \multicolumn{4}{|c|}{$\begin{array}{c}\text { Group A } \\
\text {-implants } 1.7 \mathrm{~mm} \\
+1.7 \mathrm{~mm}\end{array}$} & \multicolumn{4}{|c|}{$\begin{array}{c}\text { Group B } \\
\text {-implants } 1.7 \mathrm{~mm}+ \\
1.7 \mathrm{~mm}+1.7 \mathrm{~mm}\end{array}$} & \multicolumn{4}{|c|}{$\begin{array}{c}\text { Group C } \\
\text {-implants } 2.5 \mathrm{~mm} \\
+2.5 \mathrm{~mm}\end{array}$} & \multicolumn{4}{|c|}{$\begin{array}{c}\text { Group D } \\
\text {-implants } 2.5 \mathrm{~mm} \\
+2.5 \mathrm{~mm}+2.5 \mathrm{~mm}\end{array}$} \\
\hline & \multicolumn{4}{|c|}{ Subgroup } & \multicolumn{4}{|c|}{ Subgroup } & \multicolumn{4}{|c|}{ Subgroup } & \multicolumn{4}{|c|}{ Subgroup } \\
\hline & $\begin{array}{c}\text { EX } \\
(\mathrm{mm})\end{array}$ & $\begin{array}{l}\mathrm{KO} \\
(\mathrm{mm}\end{array}$ & $\begin{array}{l}\mathrm{RO} \\
(\mathrm{mm}\end{array}$ & $\begin{array}{l}\mathrm{PR} \\
(\%\end{array}$ & $\begin{array}{c}\mathrm{EX} \\
(\mathrm{mm})\end{array}$ & $\begin{array}{l}\mathrm{KO} \\
(\mathrm{mm}\end{array}$ & $\begin{array}{c}\text { RO } \\
(\mathrm{mm})\end{array}$ & $\begin{array}{l}\text { PR } \\
(\%)\end{array}$ & $\begin{array}{c}\mathrm{EX} \\
(\mathrm{mm})\end{array}$ & $\begin{array}{c}\mathrm{KO} \\
(\mathrm{mm})\end{array}$ & $\begin{array}{c}\mathrm{RO} \\
(\mathrm{mm})\end{array}$ & $\begin{array}{l}\text { PR } \\
(\%)\end{array}$ & $\begin{array}{c}\text { EX } \\
(\mathrm{mm})\end{array}$ & $\begin{array}{c}\mathrm{KO} \\
(\mathrm{mm})\end{array}$ & $\begin{array}{c}\mathrm{RO} \\
(\mathrm{mm})\end{array}$ & $\begin{array}{l}\text { PR } \\
(\%)\end{array}$ \\
\hline 1 & 87 & 87 & 0 & 0 & 85 & 87 & 2 & 2,4 & 86 & 88 & 2 & 2,3 & 87 & 90 & 3 & 3,4 \\
\hline 2 & 88 & 88 & 0 & 0 & 86 & 89 & 3 & 3,5 & 86 & 89 & 3 & 3,5 & 88 & 91 & 3 & 3,4 \\
\hline 3 & 90 & 90 & 0 & 0 & 87 & 90 & 3 & 3,5 & 87 & 88 & 1 & 1,1 & 86 & 89 & 2 & 3,5 \\
\hline 4 & 89 & 90 & 1 & 1,1 & 86 & 91 & 4 & 5,8 & 86 & 90 & 4 & 4,7 & 87 & 91 & 3 & 4,6 \\
\hline 5 & 89 & 60 & 1 & 1, & 88 & 91 & 3 & 3,4 & 88 & 91 & 3 & 3,4 & 86 & 90 & 4 & 4,6 \\
\hline 6 & 90 & 90 & 0 & 0 & \multirow{4}{*}{\multicolumn{8}{|c|}{$\begin{array}{l}\text { Legend: } \\
\text { EX - length - radius with the implant (experimental) } \\
\text { KO - length - radius without the implant (control) } \\
\text { RO - difference in length } \\
\text { PR - difference in length in \% }\end{array}$}} & 86 & 90 & 4 & 4,6 \\
\hline 7 & 91 & 91 & 0 & 0 & & & & & & & & & 87 & 90 & 3 & 3,5 \\
\hline 8 & 92 & 92 & 0 & 0 & & & & & & & & & 87 & 89 & 2 & 2,3 \\
\hline 9 & 90 & 90 & 0 & 0 & & & & & & & & & 88 & 91 & 3 & 3,4 \\
\hline
\end{tabular}


Table 4

Statistical evaluation of bone growth under the influence of various implant placements

\begin{tabular}{|c|c|c|}
\hline \multicolumn{3}{|c|}{ STUDENT's T-TEST } \\
\hline Group & Number of animals & p= probability \\
\hline A & 9 & 0.169 \\
\hline B & 5 & 0.0028 \\
\hline C & 5 & 0.0007 \\
\hline D & 9 & 0.0001 \\
\hline
\end{tabular}

In animals of groups B and C, placement of pins of different diameter and number, as well as the different technique of their insertion, resulted in the differences in the influence of the growth of radius (K-W ANOVA). Results are given in Table 5.

Table 5

Statistical evaluation using non-parametric K-W ANOVA

\begin{tabular}{|c|c|c|c|}
\hline \multicolumn{5}{|c|}{ Kruskal-Wallis single-factor analysis of variance } \\
\hline Group & Number of animals & Sum & Rank \\
\hline B & 5 & 31 & 4.2 \\
\hline C & 5 & 24 & 5.5 \\
\hline Total & 10 & 55 & 0.012121 \\
\hline \hline \multicolumn{2}{|c|}{0.541100} \\
\hline \multicolumn{2}{|c|}{ Correction to fit } & 0.462000 \\
\hline
\end{tabular}

Analysing the samples of operated distal radial growth plates histologically, we found, that the defect in the physis corresponded to the diameter of inserted Steinmann pin and did not further enlarge nor diminish. There has been almost no reaction of distal radial physis itself to the damage caused by implant insertion. The lesions were restored by typical process of bone healing, i.e. stages of formation of granulation tissue, fibrous and bone callus. Formation of bone bridges was noted following the extraction of implants in all cases (Plate VIII, Fig. 2). The greater the Steinmann pin diameter, the greater the bone bridge formation. There was no tendency to resorption or transformation or healing ad integrum in bone bridges in the physis.

Table 6 presents histological evaluations of changes in twelve specimens of the distal radial physis following passage of Steinmann pins of various diameters (1.7 and $2.5 \mathrm{~mm}$ ).

Table 6

Histological evaluation of the implant passage

\begin{tabular}{|c|c|c|c|c|c|c|c|c|}
\hline \multicolumn{7}{|c|}{ Histological evaluation of the implant passage through the physeal plate } \\
\hline $\begin{array}{c}\text { Specimen } \\
\text { No. }\end{array}$ & \multicolumn{9}{|c|}{1.7 mm diameter } & \multicolumn{5}{c|}{2.5 mm diameter } \\
\cline { 2 - 10 } & Trabeculae & Borders & Marrow & Sum & Trabeculae & Borders & Marrow & Sum \\
\hline 1 & 1 & 0 & 0 & 1 & 1 & 1 & 2 & 4 \\
\hline 2 & 1 & 0 & 1 & 2 & 2 & 1 & 1 & 4 \\
\hline 3 & 1 & 0 & 0 & 1 & 2 & 1 & 1 & 4 \\
\hline 4 & 1 & 1 & 0 & 2 & 1 & 1 & 1 & 3 \\
\hline 5 & 0 & 1 & 0 & 1 & 2 & 1 & 1 & 4 \\
\hline 6 & 1 & 0 & 1 & 2 & 2 & 1 & 1 & 4 \\
\hline
\end{tabular}


In the group of animals, where Steinmann pins of $1.7 \mathrm{~mm}$ diameter were used, the summation of evaluated parameters amounted to the maximum value of 2 . In the group of animals, where implants of $2.5 \mathrm{~mm}$ were used, the sum of parameters amounted in most cases 4 . The diameter of implant influenced the degree of ossification in the area of its passage through the distal radial physis and, thus, indirectly the growth of this bone.

\section{Discussion}

The surgery of physeal fractures should be carried out as atraumatically to the physis as possible, should not damage the periost in the area of the Ranvier notch, and should restore joint congruity and continuity of growth plate by precise anatomical reposition. These requirements are best met by the mini-invasive osteosynthesis. The following upper-limb physeal fractures can be treated using this method: separation of the lateral clavicular growth cartilage, separation of the proximal humeral physis, Salter-Harris type II (or rarely occuring Salter-Harris fracture type III), injury to the physes of the lateral or medial humeral condyles, intercondylar fractures of the distal humerus (epiphyseal fractures, Salter-Harris type IV), separation of the distal humeral epiphysis, physeal injuries of proximal or distal radius, separation of metacarpal epiphyses, and epiphyseal fractures of phalanges (Gál 1999).

Indication of this mini-invasive percutaneous osteosynthesis has so far been limited by vague requirements of the least possible diameter implants. Therefore some experimental studies engaged in these problems have been done. Most of them, however, employed only small experimental animals such as rabbits and dogs (Park et al. 1994; J an arv et al. 1998; Sukhiani and Holmberg 1997). Other authors studied and monitored the possibility of filling the existing defect in the physeal plate and thus preventing the bone bridge formation (Stadelmaier et al. 1995; Martiana et al. 1996), or eventually the possibility of regeneration of the growth plate (Langenskiold et al. 1989). In our opinion, the way to optimise percutaneous fracture fixation leads through experiments engaged in these problems. It is, therefore, necessary to understand the primary process of influencing the physeal plate by passage of osteosynthetic implants.

In this study we determined that the defect in the physis corresponds to the diameter of the implant, and does not further enlarge nor diminish. Physis itself has almost no reaction to the damage by the implant and healing process includes the stages of granulation tissue, fibrous, and bone callus. Bone bridges form in all lesions. They are, however, more pronounced when using pins of greater diameter. Bone bridges have neither tendency to resorption, nor to other transformation and healing ad integrum. They are impairing the further growth of the bone in dependence on their size and localisation. We consider very important fact, that the bone bridge is already formed while the implant is still in situ. At this time it has a form of a tiny cylinder along the implanted pin. Following pin extraction, the hole fills with fibrous tissue, which then ossifies, making up the process of bone bridge formation (Plate IX, Fig. 3). The bone bridge gets wider under circumstances of inflammation during healing. The localisation of the bridge plays also an important role. Bridges localised on the periphery of the physis cause mostly angulation and slight shortening of the bone and thus shortening of the limb. A bone bridge, localised in the central part of the physis, due to growth of the bone results in a cylinder shaped elongation of the growth plate, called a "tenting phenomenon". Combined bridges cause both the angulation and shortening of the bone (Havránek 1991). The localisation of the bone bridge depends on the technique of implant insertion into the physis. When repairing fracture in the growth plate using transphyseally-inserted pins (e.g., in the area of the distal radius), we can expect formation of a peripheral bridge. Crosswise implantation of pins through the physis (e.g., in the area of the distal femoral physis) results in formation of two bridges. Central bridges may be created, for example, by immobilisation of physeal injuries of the lateral condyle of humerus. 
Within the framework of this experiment, we inserted various combinations of pins into the distal physis of radius (two Steinmann pins inserted in a crosswise manner from both sides and three pins from one side of the physis). Pins crossed the physis approximately in its centre. With the larger area of physeal damage by implants of larger diameter $(2.5 \mathrm{~mm})$, the localisation of the damage is probably not as important, because even two wider implants placed from sides of the bone cause growth cessation. Only two slender pins $(1.7 \mathrm{~mm}$ in diameter) placed crosswise into the distal radial physis did not influence the growth of the bone. From the results obtained by morphometry and histology it is clear that the impairment of growth of the bone is caused by a complex effect of all bridges formed. Placement of two pins of $1.7 \mathrm{~mm}$ diameter did not influence growth of the bone, because as the bone grew, the bridges were elongating until a moment of breaking. Both, three $1.7 \mathrm{~mm}$ and two $2.5 \mathrm{~mm}$ pins, placed through the distal radial physis, influenced growth of this bone. This fact leads us to conclusion that the impairment of growth of the bone due to damage of the physeal plate depends on the summation of areas of bone bridges formed after transphyseal insertion of implants. The total area of physeal damage, caused by passage of the implant, may also depend on the angle of pin insertion. It seems that each physis has its own level of tolerance with respect to the extent of damage by transphyseal implant placement. It is only the tolerance of implant passage through the distal femoral physis in the rabbit that has been scientifically described and amounts to about $7 \%$ of the total surface area of the physis (Janarv et al. 1998).

\section{Vliv transfyzárně zavedených hřebů na růst kosti: experimentální studie u prasat}

Cílem studie bylo zjistit, jak ovlivní růst radia do délky zavedení Steinmannových hřebů o dvou různých průměrech, $v$ různém počtu a různým směrem přes distální fýzu této kosti.

Vliv transfyzárně vedených hřebů na růst radia byl sledován u 30 selat zařazených do studie ve stáŕí 2 měsíců. Zvířata byla rozdělena do 4 skupin: A $(n=10), B(n=5), C(n=5)$ a $\mathrm{D}(\mathrm{n}=10)$. Přes distální fýzu radia jim byly zavedeny hřeby ve čtyřech různých kombinacích průměru hřebu a počtu implantátů.

U zvířat skupiny A neovlivnil průchod dvou křižně zavedených Steinmannových hřebů o průměru $1,7 \mathrm{~mm}$ distální fýzou radia další růst kosti; $\mathrm{v}$ př́ípadě zvířat ve skupinách $\mathrm{B}$ (zavedeny 3 hřeby o průměru $1,7 \mathrm{~mm}$ ), $\mathrm{C}$ ( 2 křižně vedené hřeby o průměru $2,5 \mathrm{~mm}$ ) a $\mathrm{D}$ (paralelně vedené 3 hřeby o průměru 2,5 mm) došlo ke statisticky významnému ovlivnění růstu radia (Studentův t-test).

U skupin zviŕat $\mathrm{B}$ a C ovlivnilo zavedení implantátů různého průměru, počtu a odlišnou technikou průchodu přes distální fýzu radia růst této kosti rozdílně (K-W ANOVA). Histologické vyšetření prokázalo, že průměr implantátu ovlivňuje intenzitu osifikace v místě průchodu distální fýzou radia, a tím nepřímo i růst této kosti.

Výsledky této experimentální práce naznačují, že při fixaci zlomenin v růstové ploténce transfyzárně vedenými hřeby je tř̌eba brát $\mathrm{v}$ úvahu jejich průměr, počet a techniku zavedení, protože mohou navodit vznik kostních můstků v místě fýzy s následnou poruchou růstu kosti.

\section{Acknowledgements}

This work was supported by the Ministry of Health of the Czech Republic (Research Projects of IGA MZ CR Reg. No. 50-27 and Reg. No. 6849-2). We are grateful to Mgr. Otáhalová and Prof. Minař́k from the Statistical Institute of MZLU for their help with statistical data analysis.

\section{References}

BOJRAB, MJ 1993: Disease mechanisms in small animal surgery. $2^{\text {nd }}$ ed., Lea \& Febiger, Philadelphia, 1271 p. DVOŘ́A, M, NEČAS, A, ZATLOUKAL, J 2000: Complications of long bone fracture healing in dogs: functional and radiological criteria for their assessment. Acta Vet Brno 69: 107-114 
FOSSUM, TW 1997: Small Animal Surgery. Mosby-Year Book, St. Louis, 1195 p.

GÁL, P 1999: Úskalí, selhání a komplikace miniinvazivní osteosyntézy v dětské traumatologii. Zpr Úraz Chir 7: $1-8$

GOMES, LS, VOLPON, JB 1993: Experimental physeal fracture-separations treated with rigid internal fixation. J Bone Joint Surg Am 75: 1756-1764

HAVRÁNEK, P. 1991: Dětské zlomeniny. Corvus, Praha, 204 p.

HOVE, LM, ENGESAETER, LB 1997: Corrective osteotomies after injuries of the distal radial physis in children. J Hand Surg 22: 699-704

HULSE, DA, JOHNSON, AL 1999: Decision making in fracture management. In: FOSSUM, TW: Small Animal Surgery. Mosby-Year Book, Inc., St. Louis, pp. 730-733

JANARV, PM, WIKSTRÖM, B, HIRSCH, G 1998: The influence of transphyseal drilling and tendon grafting on bone growth: an experimental study in the rabbit. J Pediatr Orthop 18: 149-54

JOHNSON, AL, NEČAS, A, TOOMBS, JP 1998: Korekce radius curvus šikmou osteotomií radia. In: NEČAS, A, TOOMBS, JP, JOHNSON, AL: Zevní skeletní fixace a biologická léčba fraktur. Vector, pp. 110-113

KERSHAW, CJ, KENWRIGHT, J 1993: Epiphyseal distraction for bony bridges: a biomechanical and morphologic study. J Pediatr Orthop 13: 46-50

MARTIANA, K, LOW, CK, TAN, SK, PANG, MW 1996: Comparison of various interpositional materials in the prevention of transfyseal bone bridge formation. Clin Orthop 325: 218-24

LANE, LC 1981: Fractures of the bones, which form the elbow joint and their treatment. Trans Am Surg Assoc 9: 393-431

LANGENSKIOLD, A 1981: Surgical treatment of partial closure of the growth plate. J Pediatr Orthop 11: 3-11

LANGENSKIOLD, A, HEIKEL, HV, NEVALAINEN, T, OSTERMAN, K, VIDEMAN, T 1989: Regeneration of the growth plate. Acta anat Switz 134: 113-123

MÉTAIZEAU, JP 1983: L'ostéosynthese chez l'enfant: techniques et indications. Rev chir ortop 69: 495-511

METAIZEAU, JP, PREVOT, J, SCHMITT, M 1980: Reduction et fixation des fractures et decollements épiphyssaires de la tête radial par broche centromedullaire. Rev Chir Ortop 66: 47-49

NECAS, A 1996: Principy chirurgického ošetření fraktur u rostoucích zvířat. Sborník referátů ze IV. výroční konference ČAVLMZ, Brno, 11.-12. října, 1996, pp. 75-78

NEČAS, A 1998a: Srovnání ESF a jiných metod fixace fraktur. In: NEČAS, A, TOOMBS, JP, JOHNSON, AL: Zevní skeletní fixace a biologická léčba fraktur. Vector, pp. 158-162

NEČAS, A. 1998b: Volba metody fixace zlomeniny: zhodnocení typu fraktury a stavu pacienta. In: NEČAS, A, TOOMBS, JP, JOHNSON, AL: Zevní skeletní fixace a biologická léčba fraktur. Vector, pp. 64-74

NEČAS, A 2001: Nemoci pohybového systému. In: SVOBODA, M, SENIOR, DF, DOUBEK, J KLIMEŠ, J a kolektiv: Nemoci psa a kočky. II. díl., Noviko a.s., pp. 1359-1559

OLMSTEAD, ML 1995: Small Animal Orthopedics. Mosby-Year Book, Inc., St. Louis, 591 p.

PARK, JS, AHN, JI, OH, DI 1994: Chondrocyte allograft transplantation for damaged growth plate reconstruction. Yonsei Med J KOREA 5: 567-572

PARTIO, EK, TUOMPO, P, HIRVENSALO, E, BOSTMAN, O, ROKKANEN, P 1997: Totally absorbable fixation in the treatment of fractures of the distal femoral epiphyses. A prospective clinical study. Arch Orthop Trauma Surg 116: 213-216

ROCKWOOD, CA, WILKINS, KE, KING, RE 1984: Fractures in children. Lippincott, Philadelphia, 1136 p.

SALTER, RB, HARRIS, WR 1963: Injuries involving the epiphyseal plate. J Bone Joint Surg (Am) 45: 587-622

SLATTER, DH 1993: Textbook of Small Animal Surgery. W. B. Saunders, Philadelphia, 2362 p.

STADELMAIER, DM, ARNOCZKY, SP, DODDS, J, ROSS, H 1995: The effect of drilling and soft tissue grafting across open growth plates. A histologic study. Am J Sports Med 4: 431-35

SUKHIANI, HR, HOLMBERG, DL 1997: Ex vivo biomechanical comparison of pin fixation techniques for canine distal femoral physeal fractures. Vet Surg 26: 398-407

VON LAER, L 1984: Skelettraumata im Wachstumsalter. Hefte Unfalheilk. 166, Spinger, Berlin-Heidelberg 
Plate VIII

Gál P. et al.: Influence... pp. 319-325

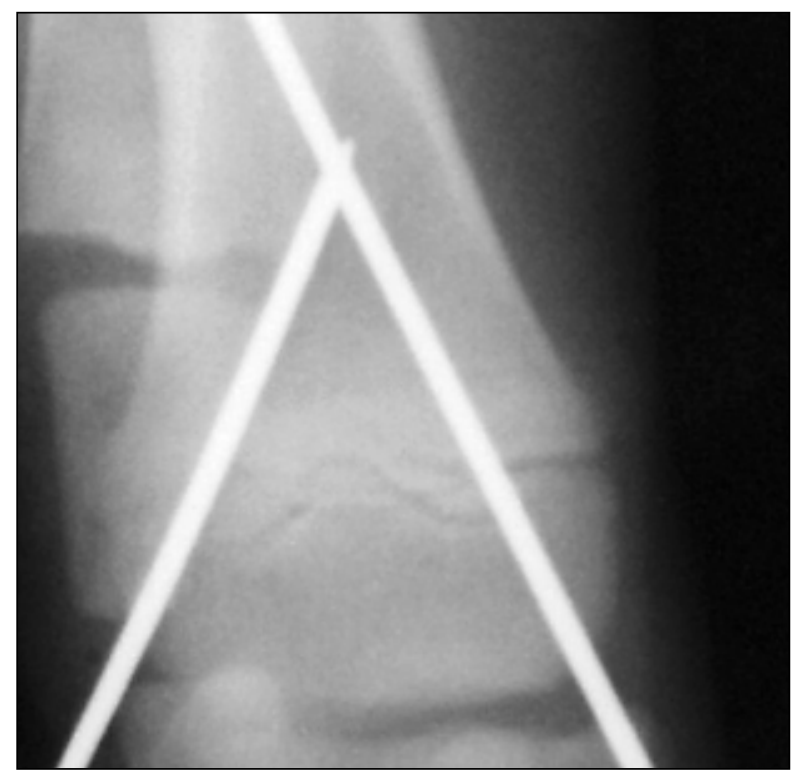

Fig. 1. Post-operation radiograph of two crossed Steinmann pins $(1.7 \mathrm{~mm})$ in the distal radial physis in a piglet.

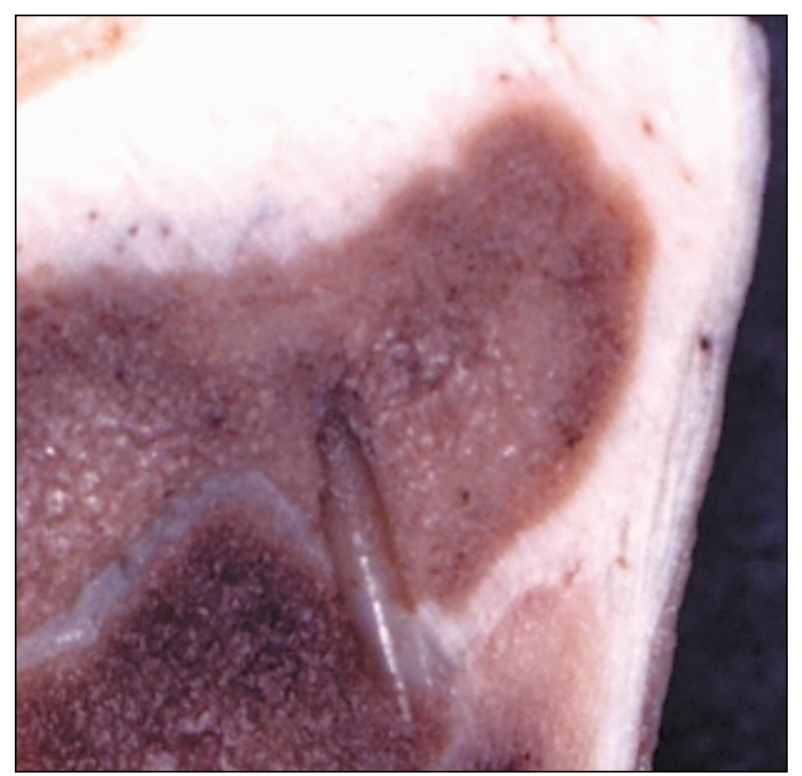

Fig. 2. The bone bridge with a border following passage of a $1.7 \mathrm{~mm}$ pin through the distal growth plate of the radius. 
Plate IX

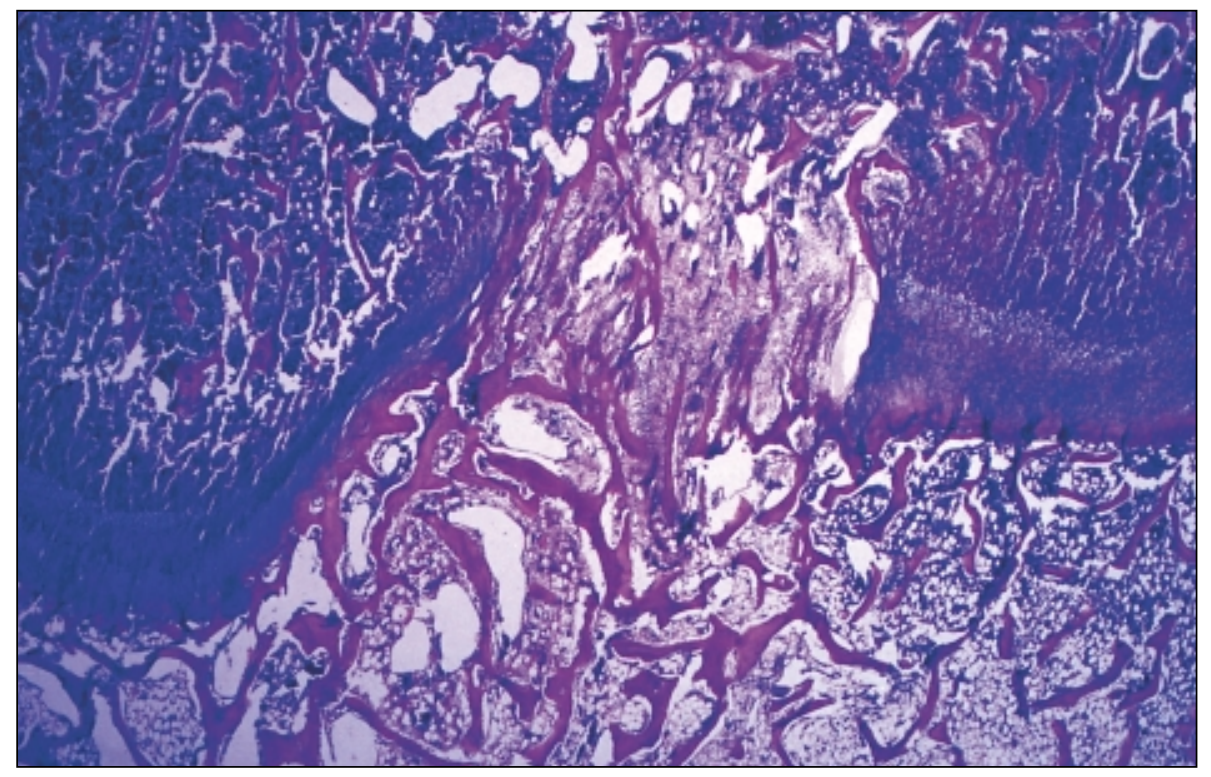

Fig. 3. The bone bridge with matured bone tissues in the distal radial physis. 